\title{
CZECH TEACHERS' ATTITUDES TOWARDS CURRICULUM REFORM IMPLEMENTATION
}

\author{
TOMÁŠ JANÍK ${ }^{\mathrm{A}}$, TOMÁŠ JANKO ${ }^{\mathrm{A}}$, KAROLÍNA PEŠKOVÁA, \\ PETR KNECHT $^{\mathrm{A}}$, and MICHAELA SPURNÁ ${ }^{\mathrm{B}}$
}

\begin{abstract}
The study focuses on the implementation of curriculum reform in grammar schools in the Czech Republic. The purpose of this study was to explore the attitudes of grammar school teachers towards the reform and its implementation. The perceived benefits of and problems with the curriculum reform were measured using closed-ended items (on a Likert scale). The research sample of this questionnaire survey consisted of 1,098 teachers from 58 schools. The results indicate that the reform has been more readily accepted in pilot schools than in non-pilot schools. In general, it can be concluded that although there was support for the main ideas behind the reform, the majority of teachers have not accepted the reform as a whole. The multiple regression analysis revealed that gender, position, length of teaching experience, and knowledge of specific characteristics of curriculum reform did not significantly contribute to teachers' acceptance of the curriculum reform.
\end{abstract}

Key words: curriculum; curriculum reform; implementation; teacher attitudes; higher secondary education; Czech Republic.

\section{Introduction}

Curriculum reform is often promoted as promising improvements in the quality of education. However, if success is to be ensured, according to Stibbe (2005), it is vital that the nature and principles of the reform are understood and accepted by those implementing them. This study investigates the attitudes of Czech grammar school teachers and school management (headteachers and deputy headteachers) towards the last curriculum reform in the Czech Republic. The curriculum reform has not had the impact on education practice expected by the wider educational community ${ }^{1}$. The focus of the research is therefore directed at the

\footnotetext{
1 One factor was insufficient teacher participation, resulting in reservations regarding the benefits of and even concerns about the reform. 
process whereby the curriculum reform was implemented from an actor-oriented perspective (see Penuel et al., 2014). The factors which may influence teachers' attitudes towards such reforms are also investigated.

\section{Curriculum transformation in the Czech Republic}

Following the political and economic upheaval of 1989 the Czech education system underwent dynamic change. Before that, Czech curriculum policy had been under the control of totalitarian government and it was not until the turn of the millennium that the system transitioned from a centrally developed curriculum to school curricula. This shift brought about a redefinition of educational policies and educational goals and thus affected all levels and dimensions of education in the Czech Republic (cf. Ministry of Education, Youth and Sport, 2001, pp. 8-10) ${ }^{2}$.

The most characteristic feature of the education transformation in the Czech Republic was the introduction of a two-level curriculum in 2001. The national curriculum was set out in Framework Education Programmes (FEPs), and the school curriculum was articulated through School Education Programmes (SEPs). These emphasized the educational autonomy of schools and the teacher's responsibility for the outcomes of the education process ${ }^{3}$. Moreover, teachers became key stakeholders in the curriculum reform in line with the general conception behind the education transformation, which emphasized decentralization and greater autonomy for schools (see Janík, 2016). However, after a decade of curriculum reform in the Czech Republic, the suspicion is that the implementation of the new curriculum system has brought a lot of difficulties for both schools and teaching staff. Thus, to fully understand the consequences of the Czech curriculum reform and its true effect on education, we need to understand teachers' perceptions of the strengths and weaknesses of the reform.

\section{Implementation of the curriculum reform}

Once a new curriculum has been developed, implementation occurs as an interactive process between curriculum developers and teachers (for further explanation see Tamir, 2004). As Figure 1 shows, curriculum forms are linked together by curriculum processes, which come as follows: curriculum development (planning), implementation, realization, attainment and revision (cf. Janík et al., 2010).

Some scholars (e.g. Spillane, 1999) suggest that teachers should be key stakeholders in the processes of curriculum development and implementation, as this strengthens their commitment and attitudes to the curriculum changes. Teachers' participation in curriculum

\footnotetext{
2 In the 1990s the state replaced the old centralized syllabi that set out the aims of each subject with curriculum documents for each school type. This was the first attempt at integrating subjects and reformulating learning outcomes.

3 The two-level curriculum reform was unveiled in the strategic document White Paper (2001). Following a pilot phase, final versions of the FEPs for the various school levels were published from 2004 onwards (primary schools - 2005; grammar schools - 2007, etc.). The nation-wide implementation phase then began and all schools had to create their own school education programmes.
} 


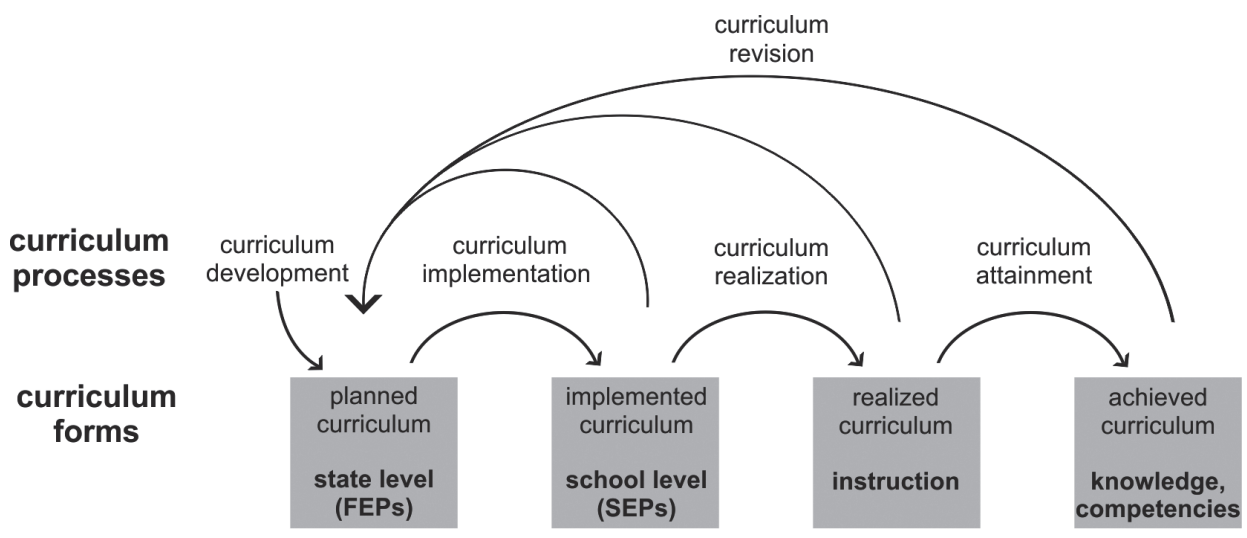

Figure 1. Intended and achieved curriculum.

development is crucial because the way teachers perceive the curriculum, their attitudes towards it, and the way they interpret it are important factors influencing teachers' attitudes towards the reform and consequently its success (Kirk \& McDonald, 2001). If they are actively involved in the process, then they are no longer just impacted by the reform. On the contrary, they become active promoters and implementers.

The enactment of curriculum materials by teachers is not a trivial step in the process of curriculum reform implementation. Failure to consider this as a critical link in the reform process has led to difficulties with many curriculum reforms (Sherin \& Drake, 2009). According to Clandinin and Connelly (1992) teachers should not only undergo natural change, but are expected to do so in directions specified by reformers. Thus, teachers' acceptance of their new curriculum-maker role remains a key issue.

The next section reviews the literature on the factors behind and reasons for teachers'attitudes to curriculum reform and considers them in terms of the opposing poles of acceptance and resistance.

Based on the review of literature dealing with factors and reasons of teachers' particular attitudes towards curriculum reforms, in the next section these attitudes are approached as oppositional orientations of acceptance and resistance.

\section{Teachers' attitudes towards curriculum reform: Between acceptance and resistance}

In general, attitudes are a summary evaluation of a psychological object (Ajzen \& Fishbein, 2000), and in classic attitude theory are considered to comprise three components: cognitive, affective, and behavioural. Teachers' attitudes towards curriculum reform usually stem from their professional identity and are underpinned by a personal interpretative framework relating to the school context, specific everyday experiences, perceptions of pupils' educational needs, and emotional aspects (Vähäsantanen \& Eteläpelto, 2011). In this context, 
Wallace and Priestley (2011) introduced the concept of teacher sense-making, which refers to the cognitive activities teachers perform when constructing meaning of policy messages. Furthermore, different ways of responding to reforms can be understood as different ways of exercising agency (Priestley et al., 2012), manifest in the way teachers engage with changing work practices (Vähäsantanen \& Eteläpelto, 2011).

Nevertheless, teachers' attitudes towards curriculum change should also be considered in relation to their own pedagogical perspectives, that is, in relation to three basic pedagogical belief patterns of curriculum (Vollstädt et al., 1999): 1) system-oriented teachers usually consider state and school level curricula as relevant to their teaching practices, 2) subject/ content-oriented teachers tend to criticize the curricula from a subject-matter perspective and 3) student-oriented teachers may view curricula as a constraint on their pedagogical work.

Teachers' attitudes to and engagement with the curriculum reform exist on a continuum from acceptance to resistance. More specifically, the factors influencing teachers' attitudes (along this continuum) to the curriculum reform can be divided into two groups: 1) contextual factors (demographical characteristics such as gender, age, length of teaching experience, position, subject specialization); and 2) subjective factors (such as knowledge of the principles of the reform, preferred type of curriculum and teacher orientation, i.e. systemoriented, student-oriented and subject/content-oriented teachers).

The relevance of contextual factors proved to be significant in a study by Erbas and Ulubay (2008), in which they found that Turkish lower-secondary school teachers with less teaching experience (6-20 years) predominately associated the implementation of the curriculum reform with an improvement in evaluation techniques whereas, teachers with more teaching experience (over 21 years) associated with innovation in the teaching-learning process and the improved use of instructional materials. In a study of physical education teachers in Hong Kong, Ha et al. (2008) showed that experienced teachers had more encouraging and positive attitudes towards the curriculum innovations than novice teachers (cf. contrasting results in Kwok, 2014; Tůmová, 2012; Smit, 2005). Gender differences were significant in a study by Haney et al. (1996) who reported that women teachers in Ohio held more positive attitudes towards the curriculum reform. Different research findings were obtained in Hong Kong by Lee (2000) who found that gender (and experience) may not be significant predictors of teacher attitudes or behavioural intentions towards curriculum change.

Concerning the relevance of subjective factors, studies by Karakhanyan, van Veen and Bergen (2011) and Janík et al. (2011a) found that familiarity with the principles of the curriculum reform was important and that teachers unfamiliar with these tended to reject the reform more vigorously. At the other end of the spectrum, Pol et al. (2013) investigated the skills Czech teachers and headteachers require in order to implement curriculum reform and found a relationship between organizational learning among teachers and curriculum development and implementation (SEPs) in schools. Vollstädt et al. (1999) revealed that most of the German teachers in their research considered themselves to be student-oriented and surprisingly these were not the most critical group. Teachers adopting a strong subject/ content-oriented position tended to reject the curriculum. System-oriented teachers were noticeably less critical of the new curriculum.

This study combines and expands these two lines of inquiry within the context of the relevant research. The success of curriculum reform is dependent not only on the quality 
of the innovated curriculum documents, but also the conditions under which the reform is implemented within schools. Since teachers are the key implementers of the curriculum change, we focused on their assessment of the new curriculum documents and their perceptions of the conditions under which the new curriculum was introduced.

\section{Method}

The purpose of this study was to explore the attitudes of Czech grammar school teachers (and headteachers and deputy headteachers) towards curriculum reform and its implementation. The research aims were twofold:

- first, to explore Czech teachers' attitudes towards the new curriculum documents and their implementation on a continuum from acceptance to resistance;

- second, to identify the factors influencing teachers' attitudes to the curriculum documents and their implementation within the Czech education system.

\section{Participants}

The sample consisted of grammar school teachers, headteachers and deputy headteachers in the Czech Republic. A total of 1,098 participants were recruited from 58 grammar schools (12 pilot schools and 46 non-pilot ones ${ }^{4}$ ). In order to compare the differences in teachers' attitudes to the curriculum reform at both pilot and non-pilot grammar schools, the schools ${ }^{5}$ were randomly sampled. Detail on the descriptive characteristics of the research sample can be found in Table 1 .

The majority of teachers were from non-pilot schools (850 teachers). In both the pilot and non-pilot schools, the largest teaching experience category was that containing teachers with the most teaching experience (over 30 years), which is relevant to the construct being investigated.

\section{Research instrument}

The research instrument was a structured questionnaire consisting of closed-ended items with a five-point Likert-scale. The items inquiring about the degree to which the reforms were accepted were formulated in line with research instruments used in similar research (e.g. Roggenbrodt, 2008; Künzli et al., 1999).

\footnotetext{
4 Pilot schools were involved in developing the two-level curriculum. They were invited by the Ministry of Education (National Institute for Education) to discuss the Framework Educational Programmes and to develop the School Educational Programmes in the "preliminary" phase of curriculum reform implementation. They were supported by and provided feedback for the Ministry of Education and served as "models" for the non-pilot schools. The non-pilot schools were not involved in the curriculum reform implementation until it entered the "official" phase and they received only limited support from the Ministry of Education.

5 A group of 75 non-pilot grammar schools was selected using random number generation (i.e. $20 \%$ of all the 377 non-pilot grammar schools). All the pilot schools were contacted. All the teachers (including headteachers) at the selected pilot and non-pilot grammar schools were then asked to participate in the survey.
} 
Table 1. Details of research sample

\begin{tabular}{|l|c|c|}
\hline Category & $\mathbf{N}$ & \% \\
\hline teachers & 1026 & 93.44 \\
\hline headteachers / deputy headteachers & 72 & 6.56 \\
\hline teachers at pilot grammar schools & 220 & 20.04 \\
\hline teachers at non-pilot grammar schools & 850 & 77.41 \\
\hline Women & 758 & 69.01 \\
\hline Men & 340 & 30.96 \\
\hline 0-5 years of teaching experience & 128 & 11.66 \\
\hline 6-10 years of teaching experience & 120 & 10.93 \\
\hline $11-15$ years of teaching experience & 128 & 11.66 \\
\hline 16-20 years of teaching experience & 158 & 14.39 \\
\hline 21-25 years of teaching experience & 172 & 15.67 \\
\hline 26-30 years of teaching experience & 154 & 14.03 \\
\hline over 30 years of teaching experience & 231 & 21.04 \\
\hline
\end{tabular}

The questionnaire consisted of two parts. The first part comprised five questions on the demographic characteristics of the respondents (gender, length of teaching experience, subject specialization, etc.). The second part was aimed at determining the degree to which the curriculum reforms were accepted and consisted of 57 closed-ended items with a fivepoint Likert-scale (i.e. teachers' views of the benefits of and problems with the curriculum reform - 39 items; teachers' general orientation toward the curriculum - 12 items; teachers' knowledge of the characteristics of the curriculum reform and related documents -6 items). Respondents indicated the extent to which they agreed with the statements on a Likertscale (from $1=$ strongly disagree to $5=$ strongly agree). The questionnaire was distributed electronically and in hard copy depending on the teacher's preference. The response rate from the pilot grammar schools was 75\% (16 were approached) and 61\% at the non-pilot schools (75 were approached).

\section{Research variables}

The dependent variable was teachers' attitudes towards the curriculum reform. The complexity of the attitudes was measured in three dimensions. The first dimension focused on teachers' statements about the reform related to the cognitive component (beliefs about the benefits, the convenience, the utility, and the value of the reform) - and the affective component (emotional response and concerns about situations related to the reform, etc.; cf. Ajzen \& Fishbein, 2000). The second dimension considered how teachers' attitudes changed because of the reform. The third dimension (behavioural component of attitudes) 
Table 2. Arithmetic means of teachers' attitudes

\begin{tabular}{|l|c|c|c|}
\hline \multicolumn{4}{|c|}{ Polarity of teachers' attitudes towards curriculum reform } \\
\hline & Resistance & Neutral & Acceptance \\
\hline Value of scores(mean) & $1-2.74$ & $2.75-3.25$ & $3.26-5$ \\
\hline Value of spread & 1.74 & 0.5 & 1.74 \\
\hline
\end{tabular}

included items regarding teachers' use of curriculum documents. Nine items were negatively formulated in relation to the construct and afterwards reversely coded (e.g. Grammar school education was at a good level before the reform).

Using the teachers' attitudes score, we calculated the arithmetic mean of all three attitudes: acceptance, resistance and neutrality (see Table 2).

The independent variables were variables that had been found to be significant in comparable research studies: gender, length of teaching experience, position, employed at a pilot or non-pilot school, general orientation toward curriculum, and knowledge of specific characteristics of curriculum reform and related documents. The values of general orientation toward curriculum and knowledge of specific characteristics of curriculum reform and related documents were used for indexing (the arithmetic mean). These two variables were entered into the multiple regression analyses during the second step, and we expected significant variations in attitudes towards the reform.

The demographic variables were the omitted variables in the multiple regression analysis. They were transformed into dummy variables so they could be used in the analysis. They were entered into the first step of the analysis, and we expected the variance of the independent variable attitudes to have low values.

\section{Dimensional analysis of data}

An exploratory factor analysis (EFA) was conducted to confirm construct validity. The data set was suitable for factor analysis (Kaiser-Meyer-Olkin, measure of sampling adequacy KMO=0.95). The Bartlett's Test of Sphericity was significant $\left(x^{2}=19999.50\right.$; $\mathrm{p}<0.00$ ). An EFA (oblimin rotation, PCA) was conducted to see if the survey items conformed to the expected theoretical underpinning. Items that did not conform were deleted as they exhibited few final commonalities or had low load values on proper factors. The factor analysis of 39 items revealed three factors, while four items were excluded (see Table 3).

The first factor related to general attitudes towards education reform (loaded by 14 items, Cronbach's $\alpha=0.87$ ). The mean score of 2.65 demonstrates the rather negative attitudes of teachers. The second factor was attitudes towards the school curriculum (loaded by 12 items; $a=0.93$ ). The mean score of this factor was 3.24. The third extracted factor was attitudes regarding the usefulness of the curriculum reform (loaded by 9 items, $\alpha=0.94$ ). The mean score of 2.74 indicated negative tendencies. 
Table 3. Factor loadings for exploratory factor analysis: teachers' attitudes towards curriculum reform

\begin{tabular}{|c|c|c|c|}
\hline \multirow{2}{*}{ Item } & \multicolumn{3}{|c|}{ Rotated factor loadings } \\
\hline & factor & factor & factor \\
\hline \multicolumn{4}{|l|}{ State whether your attitude to the SEP has changed towards } \\
\hline 1u the school & 0.72 & 0.10 & -0.03 \\
\hline $2 u$ the education goals & 0.77 & 0.21 & 0.21 \\
\hline $3 \mathrm{u}$ the subject matter & 0.76 & 0.18 & 0.22 \\
\hline $4 \mathrm{u}$ the teaching methods or forms & 0.75 & 0.13 & 0.35 \\
\hline $5 \mathrm{u}$ working with other teachers & 0.69 & 0.14 & 0.36 \\
\hline 6u cooperation with parents & 0.69 & 0.12 & 0.39 \\
\hline $7 \mathrm{u}$ cooperation with pupils & 0.74 & 0.19 & 0.36 \\
\hline $8 \mathrm{u}$ lesson planning & 0.73 & 0.17 & 0.36 \\
\hline $9 \mathrm{u}$ classroom teaching & 0.72 & 0.19 & 0.38 \\
\hline 11a Grammar school education needed a change & 0.30 & 0.64 & 0.06 \\
\hline 12a I welcome the grammar school curriculum reform & 0.28 & 0.67 & 0.35 \\
\hline 13a I am concerned about the grammar school curriculum reform & -0.11 & 0.41 & 0.21 \\
\hline $\begin{array}{l}\text { 14a The pre-reform conception of grammar school education did not } \\
\text { correspond to current requirements }\end{array}$ & 0.32 & 0.61 & 0.05 \\
\hline 15a Grammar school education was excessively encyclopaedic & 0.30 & 0.53 & 0.10 \\
\hline $\begin{array}{l}\text { 16a The pre-reform level of grammar school education was at a good } \\
\text { level }\end{array}$ & 0.16 & 0.59 & -0.11 \\
\hline $\begin{array}{l}\text { 17a There was sufficient manoeuvrability to improve the grammar } \\
\text { school profile before the reform }\end{array}$ & 0.25 & 0.53 & 0.01 \\
\hline 21a The reform risks introducing endless latitude & -0.17 & 0.54 & 0.19 \\
\hline 22a The reform risks introducing excessive formalism & -0.09 & 0.42 & 0.36 \\
\hline 23a The reform increases the workload with no guarantee of success & -0.09 & 0.47 & 0.38 \\
\hline 24a The reform risks lowering pupils' learning achievements & -0.04 & 0.61 & 0.31 \\
\hline 26a I would rather teach the previous curriculum & 0.20 & 0.67 & 0.29 \\
\hline 27a The previous curriculum document was outdated & 0.26 & 0.65 & 0.16 \\
\hline 28a The previous curriculum document was fine to use & 0.19 & 0.63 & 0.13 \\
\hline 20a The reform provides an opportunity to develop the school profile & 0.20 & 0.37 & 0.47 \\
\hline Name the situations when the SEP is helpful for you for & & & \\
\hline $5 \mathrm{f}$ informing parents about the goals and subject matter & 0.20 & 0.17 & 0.60 \\
\hline 6f structuring subject matter in accordance with a thematic plan & 0.16 & 0.19 & 0.70 \\
\hline $7 \mathrm{f}$ setting teaching goals & 0.22 & 0.16 & 0.76 \\
\hline 8f planning lessons & 0.26 & 0.18 & 0.72 \\
\hline 9f considering teaching aims & 0.22 & 0.26 & 0.71 \\
\hline 10 f reflecting the pupil learning outcomes & 0.28 & 0.20 & 0.68 \\
\hline
\end{tabular}


Table 3. Continued

\begin{tabular}{|c|c|c|c|}
\hline \multirow{2}{*}{ Item } & \multicolumn{3}{|c|}{ Rotated factor loadings } \\
\hline & factor & factor & factor \\
\hline $11 \mathrm{f}$ choosing teaching methods & 0.39 & 0.15 & 0.65 \\
\hline $12 \mathrm{f}$ choosing teaching aids and media & 0.39 & 0.12 & 0.65 \\
\hline $\begin{array}{l}13 f \text { conversing with teachers responsible for departmental subject } \\
\text { planning }\end{array}$ & 0.28 & 0.14 & 0.69 \\
\hline $\begin{array}{l}14 \mathrm{f} \text { conversing with teachers not responsible for departmental } \\
\text { subject planning }\end{array}$ & 0.31 & 0.09 & 0.70 \\
\hline $15 \mathrm{f}$ determining core subject matter for pupils & 0.15 & 0.14 & 0.73 \\
\hline $\mathrm{A}$ & 0.87 & 0.93 & 0.94 \\
\hline Eigenvalues & 15.15 & 3.3 & 2.61 \\
\hline$\%$ of variance & 38.84 & 8.48 & 6.72 \\
\hline
\end{tabular}

Table 4. Factor loadings for exploratory factor analysis: teachers' general orientation toward curriculum

\begin{tabular}{|c|c|c|c|}
\hline \multirow{2}{*}{ Items } & \multicolumn{3}{|c|}{ Rotated factor loadings } \\
\hline & Factor & Factor & Factor \\
\hline $5 p$ The pupils are most important to me & 0.81 & 0.09 & 0.09 \\
\hline $7 \mathrm{p}$ When preparing lessons, I mainly consider pupil needs & 0.80 & 0.00 & 0.06 \\
\hline $2 \mathrm{p}$ The school should primarily provide discipline-based knowledge & -0.02 & -0.07 & 0.81 \\
\hline $\begin{array}{l}3 p \text { When preparing lessons, I primarily consider how the knowledge } \\
\text { is organized within the discipline }\end{array}$ & 0.09 & -0.04 & 0.82 \\
\hline 8p I could manage without the FEP or SEP & -0.07 & 0.77 & 0.12 \\
\hline 9p I find inspiration for my lessons in the FEP and SEP & -0.02 & 0.83 & 0.04 \\
\hline 10p When planning lessons, I follow the SEP & 0.09 & 0.76 & 0.03 \\
\hline $\begin{array}{l}\text { Eigenvalues } 0.72 \\
\mathrm{~A}\end{array}$ & 2.67 & 2.53 & 1.50 \\
\hline$\%$ of variance & 22,22 & 21,07 & 12,42 \\
\hline
\end{tabular}

A second EFA (varimax rotation, PCA) was similarly conducted in relation to the dimension concerning teachers' general orientation toward the curriculum $(\mathrm{KMO}=0.74)$. The Bartlett's Test of Sphericity was significant $\left(\mathrm{x}^{2}=3116.69 ; \mathrm{p}<0.00\right)$. Three clear factors were obtained: student-oriented, subject/content-oriented, and system-oriented views 
on curriculum. The items that did not conform were deleted as they exhibited few final commonalities or had small loadings on the true factors (see Table 4).

\section{Findings: Teachers' attitudes to curriculum reform}

The teachers' overall attitudes were assessed by examining the score obtained for the reform and problems with the reform $(x=2.85 ; \mathrm{SD}=0.63)$. The respondents who accepted the reform constituted the smallest group in the sample $(15 \%, \mathrm{n}=149)$. Nevertheless, over half of the respondents were neutral on the reform $(55 \%, \mathrm{n}=585)$. The reform was not acceptable to 321 respondents $(30 \%)^{6}$. One can therefore observe that the curriculum reform was not generally accepted amongst Czech grammar school teachers. The fact that teachers often take a neutral stand on curriculum reforms and, as a result, frequently only support reform initiatives in a formal sense has been identified in other research as well (cf. Bümen, Çakar, \& Yildiz, 2014; Park \& Sung, 2013; Rekkor, Ümarik, \& Loogma, 2013, etc.).

The scores of the female and male teachers suggest male teachers were more resistant $(x=2.68, S D=0.05)$ than female teachers, who tended to be more neutral $(x=2.76$, $\mathrm{SD}=0.03)$. However, the analysis of variance shows that there was no significant difference between the male and female teachers $(\mathrm{F}=8399.60, \mathrm{p}=0.22)$. These results correspond with the findings of Lee (2000) but not with those reported by Haney et al. (1996), who found the opposite.

Another question was whether the attitudes towards curriculum changes differed from school to school. The results indicate statistically significant differences $(\mathrm{F}=3438.88$, $\mathrm{p}<0.000)$ between teachers working at the pilot schools $(\mathrm{n}=220, \mathrm{x}=2.93, \mathrm{SD}=0.06)$ and those working at non-pilot schools $(\mathrm{n}=850, \mathrm{x}=2.68, \mathrm{SD}=0.06)$. The respondents from the pilot grammar schools were much more accepting of the reform. These findings are not specific to the Czech Republic, as research results from other countries (e.g. Vollstädt et al., 1999) indicate greater levels of acceptance are typically found in pilot schools - this is usually related to the fact that pilot-school teachers are more involved in (pro)reform activities and discuss them more within schools.

Length of teaching experience was not revealed to be significant. The attitudes ranged along the continuum from resistant to neutral, as seen in Table 5. The cohorts of teachers with medium teaching experience (11-25 years) had the lowest mean score, indicating they were most resistant $(n=231, x=2.74, S D=0.06)$. However, the analysis of variance (post-hoc Tukey test) did not confirm a significant difference between the groups $(\mathrm{F}=1.32, \mathrm{p}=0.24)$.

The three factors obtained through the exploratory factor analysis indicated that most respondents tended to be student-oriented (primary focus on student needs during curriculum implementation), with most teachers achieving the highest score on this factor $(n=796$, $\mathrm{x}=4.44, \mathrm{SD}=0.02$ ). Far fewer teachers were subject/content-oriented (emphasis on subject content and how it relates to the field of study; $\mathrm{n}=106, \mathrm{x}=3.43, \mathrm{SD}=0.02$ ) or system-oriented

\footnotetext{
6 The responses were incomplete in 43 cases out of the total 1,098 respondents, i.e. approximately 4\%, and were not analysed.
} 
Table 5. Mean score of attitudes according to length of teaching experience

\begin{tabular}{|l|c|c|c|}
\hline Length of teaching experience & Mean & SD & N \\
\hline 0-5 years & 2.79 & 0.08 & 135 \\
\hline 6-10 years & 2.84 & 0.08 & 120 \\
\hline 11-15 years & 2.62 & 0.08 & 128 \\
\hline 16-20 years & 2.64 & 0.07 & 158 \\
\hline 21-25 years & 2.70 & 0.07 & 172 \\
\hline 26-30 years & 2.83 & 0.07 & 154 \\
\hline over 30 years & 2.74 & 0.06 & 231 \\
\hline
\end{tabular}

(seeing their work as part of the wider education system and a predominant focus on meeting the demands of the state curriculum; $\mathrm{n}=26, \mathrm{x}=2.78, \mathrm{SD}=0.02$ ). ${ }^{7}$

The results of this inquiry into extent of curriculum reform acceptance showed that system-oriented teachers thought the curriculum more beneficial. The system-oriented respondents substantiated their acceptance of the reform by stating that the new curriculum documents were particularly useful for lesson planning. In addition, the regression analysis indicated that teacher orientation was a significant predictor of curriculum reform acceptance (see further). The student-oriented teachers' attitudes to the reform were neutral. They particularly liked the greater decision-making freedom provided by the new reform. On the other hand, this cohort was rather restrained on the necessity for (indispensability of) the new curriculum documents (FEP and SEP). The subject/content-oriented cohort least liked the curriculum reform. Their resistance to the curriculum reform was characterized by quite strong disagreement about the necessity for (indispensability of) the newly implemented curriculum documents.

\section{Relationships between subjective and contextual factors and teachers' attitudes towards} the curriculum reform

In the following section, we describe the predictors of grammar school teachers' attitudes for which we had good theoretical grounding (see the previous sections). More specifically, we differentiate between contextual factors (gender, length of teaching experience, position) and subjective factors regarded (teachers' knowledge of specific characteristics of curriculum reform and related documents; teachers' orientation toward curriculum; see also section 3 of this study).

\footnotetext{
7 The remainder of the teachers $(15.48 \%, n=170)$ were unscaled as they had no clear views of the curriculum.
} 
Table 6. Factors influencing teachers' acceptance of curriculum reform (summary of regression analysis results obtained using enter method)

\begin{tabular}{|l|c|c|c|}
\hline Model & B & SE B & $\beta$ \\
\hline Step 1 & & & \\
\hline Constant & 2.91 & 0.04 & \\
\hline Gender & -0.16 & 0.04 & $-0.12^{* * *}$ \\
\hline Position & 0.22 & 0.08 & $0.09^{* *}$ \\
\hline Teaching experience (0-5 years) & 0.17 & 0.07 & $0.09^{*}$ \\
\hline Step 2 & & & \\
\hline Constant & 1.43 & 0.14 & \\
\hline Gender & -0.08 & 0.03 & $-0.06^{*}$ \\
\hline Knowledge of the reform & 0.04 & 0.02 & $0.05^{*}$ \\
\hline System-oriented view & 0.49 & 0.02 & $0.68^{* * *}$ \\
\hline
\end{tabular}

A two-step forced entry regression analysis was performed in order to explore the variability of the variance of attitudes (considering all the independent variables). We expected teachers' knowledge of specific characteristics of curriculum reform and related documents and teachers' general orientation toward the curriculum to be significant variables, but not the demographic variables. Multiple regression using the enter method was conducted in two steps. In the first step, the following independent (dummy) variables were included in the regression model: length of teaching experience (coded 1 for a particular span of teaching experience, in other cases 0$)$, position ( 1 for teachers in the management team and 0 for the remaining teachers) and gender ( 1 and 0 indicated male and female respectively). In the second step, teachers' knowledge of specific characteristics of curriculum reform and related documents and teachers' orientation toward the curriculum were entered as the crucial variables, and these were analysed to determine their value in explaining the dependent variable of attitudes (see Table 6).

The results of the multiple regression analysis revealed that the demographic variables (e.g. gender, length of teaching experience, position) did not play a significant role in influencing teachers' attitudes. The demographic variables explained $3 \%$ of the variance of the independent variables. The second step was to enter the independent variables of substantive theoretical importance. The variance of teachers' attitudes increased by $48 \%$. According to the model (see Table 6), the most relevant variable seems to be teachers' system-oriented view on the curriculum (standardized $\beta=0.68, \mathrm{p}<0.001$ ). This indicates that system-oriented teachers tend to be most accepting of the curriculum reform (in comparison to the other cohorts). A statistically significant relationship to the attitudes towards the reform was not found for either the student-oriented teachers or the subject/content-oriented teachers. Two other independent variables met the significance level $(0.05)$ required for 
entry into the regression model: gender (standardized $\beta=-0.06$; female teachers tended to be significantly more accepting of the reform than the male teachers) and knowledge of specific characteristics of the curriculum reform and related documents (standardized $\beta=0.05$; respondents characterizing themselves as knowledgeable of the reform were more likely to accept it). However, their $\beta$-values do not suggest a strong relationship with attitudes towards curriculum reform.

The results of the multiple regression analysis did not support the assumption that the experienced teachers have more positive attitudes toward the curriculum innovations than the novice teachers and vice versa (cf. Erbas \& Ulubay, 2008; Ha et al., 2008; Roggenbrodt, 2008). Thus, we are unable to find support for Tůmová's (2012) finding that Czech primary and lower secondary school teachers with more teaching experience tend to be more sceptical about the benefits of the reform. The cohort of system-oriented teachers is negligible in this respect, meaning that the teachers did not accept the curriculum reform extensively. In general, although the primary objective of the reform was to decentralize the curriculum and provide greater autonomy for teachers, our survey findings show that this aim has not yet been met. The two largest groups of teachers identified in our study (subject/ content-oriented and student-oriented) may feel insecure. Regardless of length of teaching experience and knowledge of the specific characteristics of the reform, subject/content oriented teachers may be worried because they may feel a decline in knowledge (Young, 2013), and student-oriented teachers may struggle because of the increased formalism and reduced autonomy resulting from the curriculum reform, which contrasts with the widely promoted objectives of the reform.

\section{Conclusions and implications}

The results of our survey show that in general the last curriculum reform has been accepted by the Czech grammar school teachers to a limited extent. The group of teachers accepting the reform was smaller than the groups that did not or that adopted a neutral attitude. A significant finding of our study is that the reform was accepted more in pilot grammar schools than in non-pilot grammar schools. Furthermore, differences in levels of acceptance amongst teachers with various lengths of teaching experience, and different positions in the school (e.g. teachers/headteachers) were not statistically significant. The teachers' general orientation toward the curriculum is another important factor in terms of whether they accept the curriculum reform. Our results show that system-oriented teachers were most favourably inclined towards the reform whereas the student-oriented and subject/content-oriented teachers were not particularly in favour or against.

The biggest limitation of the study is the difficulty in comparing it to similar studies on curriculum reforms in other countries. Curriculum reforms are introduced with various aims in mind and in different education systems, so the research findings should be interpreted within the context and under the conditions the curriculum reform was carried out in the Czech Republic. As related qualitative research (e.g. Janík et al., 2011) indicates, these conditions were an important influence on the teachers' attitudes to the curriculum reform. One possible reason for the prevailingly neutral attitudes of the Czech grammar schools' teachers towards the curriculum reform may be that the teachers were given insufficient 
support regarding development and implementation of curriculum reform. The dominant image of teachers as curriculum implementers, perpetuated by education policy and school administration, portrays curriculum implementation as a mechanistic, centrally-determined process in which the teachers are the alienated executors of someone else's plans and intentions. This is probably why many curriculum reforms are only marginally successful and their effects become invisible over time as funds and energy disappear (Connelly, 2013). Our findings are comparable, within the limits of our reform context, with other findings that teachers' have reservations regarding curriculum reform and implementation (cf. Park \& Sung, 2013; Porubský, Trnka, Poliach, \& Cachovanová, 2015; Rekkor, Ümarik, \& Loogma, 2013). Gitlin and Margonis (1995) state that acts of resistance by teachers are often motivated out of good sense as they indicate the importance of altering authority relations. This is highly relevant to the Czech Republic (and probably to former communist countries in general), where the education system is hampered by low levels of expertise among teachers, headteachers and policy-makers (Straková \& Simonová, 2013). Discourses of resistance can enable teachers to see themselves differently, creating an awareness of their professional knowledge, capabilities and identities, which may subsequently even serve as a vehicle for improving the quality of education.

Some recommendations can be made based on the findings of this study. As the pilot school teachers were more accepting of the reform, disseminating information prior to implementation could be a means of preparing teachers for the forthcoming changes and of stimulating cooperation and discussion (Halbert \& MacPhail, 2010). This could be developed during subsequent phases of implementation to introduce the concept of "deep learning communities" (Fullan, 2001), providing an environment at the school and local levels for the sharing of expertise and experience (collaborative learning framework). In addition, it would give headteachers and teachers an opportunity to share their attitudes and concerns on the expectations of state departments and in relation to their school (Halbert \& MacPhail, 2010). The concept of learning communities can be also supported by the findings of a study by Pol et al. (2013) which found that Czech teachers consider work on the curriculum at the school level as systematic under the condition of collaboration within the whole school. In this respect, the on-site intensive school curriculum development is an important aspect of organizational learning at Czech schools. This requires further research and more sophisticated theorizing of teachers' attitudes towards curriculum reform, especially from the long-term perspective and in different educational settings.

In addition, because the methodology employed in this study suffers from an overreliance on Likert scaling, further qualitative data analysis of open-ended questions included in the questionnaire could enrich our understanding of teachers' attitudes towards the curriculum reform to a greater extent.

\section{Acknowledgements}

This study received support from a Czech Scientific Foundation project, Between Acceptance and Resistance: Teachers' perceptions of curricular changes 10 years into the reform implementation (GA15-05122S) and from the Employment of Newly Graduated Doctors of Science for Scientific Excellence (CZ.1.07/2.3.00/30.0009) co-financed from the 
European Social Fund and the state budget of the Czech Republic. We wish to acknowledge the insightful feedback and constructive suggestions provided by the anonymous reviewers and the journal editors. The authors also want to thank Marie Doskočilová, Lisa Middelberg and Anne Johnson for language adjustments and comments on the preliminary versions of the paper.

\section{References}

Ajzen, I., \& Fishbein, M. (2000). Attitudes and the attitude-behavior relations: Reasoned and automatic processes. European Review of Social Psychology, 11, 1-33. Retrieved from: https://doi. org/10.1080/14792779943000116

Bümen, N. T., Çakar, E., \& Yildiz, D. G. (2014). Curriculum fidelity and factors affecting fidelity in the Turkish context. Educational Sciences: Theory \& Practice, 14, 219-228. Retrieved from: https:// doi.org/10.12738/estp.2014.1.2020

Clandinin, D. J., \& Connelly, F. M. (1992). Teacher as curriculum maker. In P. Jackson (Ed.), Handbook of curriculum research (pp. 363-401). New York: MacMillan.

Connelly, F. M. (2013). Joseph Schwab, curriculum, curriculum studies and educational reform. Journal of Curriculum Studies, 45, 622-639. Retrieved from: http://dx.doi.org/10.1080/00220272. 2013.798838

Duke, D. (2014). The challenges of educational change. Boston: Pearson Education.

Erbas, A. K., \& Ulubay, M. (2008). Implementation of the new Turkish primary education mathematics curriculum in the sixth grade: A survey of teachers' views. The New Educational Review, 16, 5176.

Fullan, M. (2001). Leading in a culture of change. San Francisco: Jossey Bass.

Gitlin, A., \& Margonis, F. (1995). The political aspect of reform: Teacher resistance as good sense. American Journal of Education, 103, 377-405. Retrieved from: https://doi.org/10.1086/444108

Greger, D., \& Walterová, E. (2007). In pursuit of educational change: The transformation of education in the Czech Republic. Orbis Scholae, 1, 11-44.

Ha, A. S., Wong, A. C., Sum, R. K., \& Chan, D. W. (2008). Understanding teachers' will and capacity to accomplish physical education curriculum reform: The implications for teacher development. Sport, Education and Society, 13, 77-95.

Halbert, J., \& MacPhail, A. (2010). Curriculum dissemination and implementation in Ireland: Principal and teacher insight. Irish Educational Studies, 29, 25-40. Retrieved from: https://doi. org/10.1080/03323310903522677

Haney, J. J., Czerniak, C. M., \& Lumpe, A. T. (1996). Teacher beliefs and intentions regarding the implementation of science education reform strands. Journal of Research in Science Teaching, 33, 971-993. DOI: 10.1002/(SICI)1098-2736(199611)33:9<971::AID-TEA2>3.0.CO;2-S

Janík, T. (2016). Curriculumreform und ihre Implementierung: Forschungsergebnisse und Empfehlungen [Curriculum reform and its implementation: research results and recommendations]. In T. Janík, Aktuelle Entwicklungen im Bildungsbereich in der Tschechischen Republik: Curriculum - Unterricht - Lehrerbildung (pp. 37-49). Berlin: Waxmann.

Janík, T., Knecht, P., Kubiatko, M., Pavlas, T., Slavík, J., Solnička, D., \& Vlček, P. (2011). Kvalita školy a kurikula: od expertního šetrení ke standardu kvality [The quality of school and curriculum: From expert survey towards standard of quality]. Praha: Výzkumný ústav pedagogický.

Janík, T., Knecht, P., Najvar, P., Pavlas, T., Slavík, J., \& Solnička, D. (2010). Kurikulární reforma na gymnáziích: $v$ rozhovorech s koordinátory pilotních a partnerských škol [The curriculum reform at gymnasium: Interviews with coordinators at pilot and partner schools]. Praha: Výzkumný ústav pedagogický. 
Karakhanyan, S., van Veen, K., \& Bergen, T. C. M. (2011). Teachers' voices in the context of higher education reforms in Armenia. European Journal of Education, 46, 508-523. Retrieved from: https://doi.org/10.1111/j.1465-3435.2011.01497.x

Kirk, D., \& McDonald, D. (2001). Teacher voice and ownership of curriculum change. Journal of Curriculum Studies, 33, 551-567. Retrieved from: https://doi.org/10.1080/00220270119157

Künzli, R., Bähr, K., Fries, A. V., Ghisla, G., Rosenmund, M., \& Seliner-Müller, G. (1999). Lehrplanarbeit. Über den Nutzen von Lehrplänen für die Schule und ihre Entwicklung [Curriculum development. About the benefits of planned curriculum for schools and their development]. Chur: Rüegger.

Kwok, P. W. (2014). The role of context in teachers' concerns about the implementation of an innovative curriculum. Teaching and Teacher Education, 38, 44-55. Retrieved from: https://doi. org/10.1016/j.tate.2013.11.002

Lee, J. Ch. (2000). Teacher receptivity to curriculum change in the implementation stage: The case of environmental education in Hong Kong. Journal of Curriculum Studies, 32, 95-115. Retrieved from: https://doi.org/10.1080/002202700182871

Ministry of Education, Youth and Sport (2001). National programme for the development of education: White paper. Prague: Institute for Information on Education.

Park, M., \& Sung, Y. K. (2013). Teachers' perceptions of the recent curriculum reforms and their implementations: What can we learn from the case of Korean elementary teachers? Asia Pacific Journal of Education, 33, 15-33. Retrieved from: https://doi.org/10.1080/02188791.2012.756391

Penuel, W. R., Rachel, S. P., \& Harris, C. J. (2014). Analysing teachers' curriculum implementation from integrity and actor-oriented perspectives. Journal of Curriculum Studies, 46, 751-777. Retrieved from: https://doi.org/10.1080/00220272.2014.921841

Pol, M., Hloušková, L., Lazarová, B., Novotný, P. \& Sedláček, M. (2013). Když se školy učí [When schools learn]. Brno: Masarykova univerzita.

Porubský, Š., Trnka, M., Poliach, V., \& Cachovanová, R. (2015). Curricular reform in Slovakia regarding the attitudes of basic school teachers. Pedagogická orientace, 25, 777-797. Retrieved from: https://doi.org/10.5817/PedOr2015-6-777

Rekkor, S., Umarik, M., \& Loogma, K. (2013). Adoption of national curricula by vocational teachers in Estonia. Journal of Vocational Education and Training, 65, 489-506. Retrieved from: https://doi.or $\mathrm{g} / 10.1080 / 13636820.2013 .841277$

Research Institute of Education (2007). Framework educational programme for basic education. Prague: Research Institute of Education.

Roggenbrodt, G. (2008). Akzeptanz komplexer Schulentwicklungsprozesse bei schulischen Akteuren, aufgezeigt am Beispiel des Schulversuchs ProReKo [Complexity of the processes of school development and their acceptance by stakeholders at schools; on the example of school pilot project ProReKo]. Bildung und Erziehung, 61, 321-351. Retrieved from: https://doi.org/10.7788/ bue.2008.61.3.321

Sherin, M. G., \& Drake, C. (2009). Curriculum strategy framework: Investigating patterns in teachers' use of a reform-based elementary mathematics curriculum. Journal of Curriculum Studies, 41, 467-500. Retrieved from: https://doi.org/10.1080/00220270802696115

Smit, B. (2005). Teachers, local knowledge, and policy implementation: A qualitative policypractice inquiry. Education and Urban Society, 37, 292-306. Retrieved from: https://doi. org/10.1177/0013124505275426

Spillane, J. (1999). External reform initiatives and teachers' efforts to reconstruct their practice: The mediating role of teachers' zones of enactment. Journal of Curriculum Studies, 31, 143-175. Retrieved from: https://doi.org/10.1080/002202799183205

Stibbe, G. (2005). Qualitätsentwicklung im Schulsport durch Schulprogramme [Quality development in school sports through school programs]. In A. Gogoll \& A. Menze-Sonneck (Eds.), Qualität im Schulsport (pp. 136-141). Hamburg: Czwalina. 
Straková, J., \& Simonová, J. (2013). Assessment in the school systems of the Czech Republic. Assessment in Education: Principles, Policy \& Practice, 20, 470-490. Retrieved from: https://doi. org/10.1080/0969594x.2013.787970

Tamir, P. (2004). Curriculum implementation revisited. Journal of Curriculum Studies, 36, 281-294.

Tůmová, A. (2012). Effects of age and length of professional experience on teachers' attitudes to curriculum reform. Central European Journal of Public Policy, 6, 84-99.

Vähäsantanen, K., \& Eteläpelto, A. (2011). Vocational teachers' pathways in the course of a curriculum reform. Journal of Curriculum Studies, 43, 291-312. Retrieved from: https://doi.org/10.1080/00220 272.2011.557839

Vollstädt, W., Tillmann, K. J., Rauin, U., Höhmann, K., \& Tebrügge, A. (1999). Lehrpläne im Schulalltag. Eine empirische Studie zur Akzeptanz und Wirkung von Lehrplanen in der Sekundarstufe I [Curriculum in everyday school life. An empirical survey on the acceptance and effects of planned curriculum in lower secondary schools]. Opladen: Leske + Budrich. Retrieved from: https://doi.org/10.1007/978-3-322-97422-8_4

Wallace, C. S., \& Priestley, M. (2011). Teacher beliefs and the mediation of curriculum innovation in Scotland: A socio-cultural perspective on professional development and change. Journal of Curriculum Studies, 43, 357-381. Retrieved from: https://doi.org/10.1080/00220272.2011.563447

Young, M. (2013). Overcoming the crisis in curriculum theory: A knowledge-based approach. Journal of Curriculum Studies, 45, 101-118. Retrieved from: https://doi.org/10.1080/00220272.2013.764505

anstitute for Research in School Education,

Faculty of Education,

Masaryk University,

Poříčí 31,

60300 Brno,

Czech Republic

Email: peskova@ped.muni.cz

${ }^{b}$ Department of Educational Sciences,

Faculty of Arts,

Masaryk University,

Arna Nováka 1,

60200 Brno,

Czech Republic 